\title{
Implications of biofuel production in the Western Cape province, South Africa: A system dynamics modelling approach
}

\author{
Willem Jonker ${ }^{1}$, Alan Colin Brent ${ }^{1,2 *}$, Josephine Kaviti Musango ${ }^{3}$, \\ Imke de Kock ${ }^{1}$ \\ 1. Department of Industrial Engineering, and the Centre for Renewable and Sustainable Energy Studies, \\ Stellenbosch University, Private Bag X1, Matieland 7602, South Africa. \\ 2. Sustainable Energy Systems, School of Engineering and Computer Science, Victoria University of Wellington, \\ Kelburn, Wellington 6012, New Zealand. \\ 3. School of Public Leadership, and the Centre for Renewable and Sustainable Energy Studies, Stellenbosch \\ University, Private Bag X1, Matieland 7602, South Africa.
}

\begin{abstract}
The national government instated a mandatory blending policy to facilitate the uptake and establishment of a biofuels sector in South Africa. Uncertainty exists, however, regarding the implications and effects of producing biofuels within the Western Cape province, as part of a strategy of the province to transition to a green economy. This investigation was carried out as an effort to simulate the biofuel production within the Western Cape under certain project and policy considerations. A system dynamics model was developed to identify key strategic intervention points that could strengthen the business case of biofuel production. The model showed a feasible business case for bioethanol production, with the best case showing an internal rate of return of $23 \%$ (without government subsidy), and an emissions reduction of $63 \%$ when compared with coal. It is recommended that special consideration be given to the location of bioethanol production facilities, as operational costs can be minimised by incorporating invasive alien
\end{abstract}

land-clearing schemes as part of the bioethanol production. The model further showed that mediumto-large-scale biodiesel production in the province is not feasible under the given model assumptions, as the positive effects of local biodiesel production do not justify the required government subsidy of ZAR 4.30 per litre. It is recommended that a different approach be investigated, where multiple on-site small-scale biodiesel production facilities are used, thus utilising multiple feedstock options and minimising capital expenditure.

Keywords: green economy; transportation; blending; uncertainty; complexity

Journal of Energy in Southern Africa 28(1): 1-12

DOI: http://dx.doi.org/10.17159/2413-3051/2017/v28i1a1457

Published by the Energy Research Centre, University of Cape Town ISSN: 2413-3051 http://journals.assaf.org.za/jesa

Sponsored by the Department of Science and Technology

\footnotetext{
* Corresponding author: Tel: +27 (0)21 808 9530;

Email: acb@sun.ac.za
} 


\section{Introduction}

Sustainable development is a well-established concept, and recognises the interdependence between the environment, the economy, and human society. A variety of concepts and policies were established to facilitate the incorporation of sustainable development, where one of the more recent concepts is that of a green economy. The United Nations Environment Programme (UNEP) describes the green economy as: 'an economy that will result in improved human well-being and social equity, while significantly reducing environmental risks and ecological scarcities' (UNEP, 2010). The green economy principle is especially applicable to developing countries, like South Africa, where management and use of natural resources play a critical role to sustain economic growth and the population's livelihood.

The South African government, as part of a sustainable development initiative, described its vision to transform the South African economy to a lowcarbon, environmentally sustainable, and resilient economy in the National Development Plan (NDP) (National Planning Commission, 2012). The NDP stipulates various policies concerning sustainable transition, at a national level, which need to be implemented at a provincial level. The Western Cape Government, subsequently, published a framework ('Green is smart') to guide the province's change into 'the leading green economic hub of the African continent' (Western Cape Government, 2013). The framework identifies clean energy and transport efficiency as two of the major role players in establishing a green economy. The need for clean energy, coupled with the national mandate to diversify the energy supply mix, established biofuel as an important role player in the transition a green economy. The mandatory blending policy (officially effective October 2015, but not yet realised) calls for fossil fuel-based petrol and diesel to be blended with $2-10 \%$ bioethanol and $5 \%$ biodiesel, respectively (Department of Energy (DOE), 2012).

On a national level, manufacturers were granted biofuel production licences. The Western Cape, however, did not see any notable interest from investors to establish a large-scale biofuel production facility. The lack of interest may be due to pricing policy structure uncertainties, as well as general uncertainties regarding the feasibility and effects of large-scale biofuel production in the Western Cape (DOE, 2014). In order to address the uncertainties involved, biofuel production may be recognised as a complex system with various interactions, interrelationships and interdependencies of which the effects are often unforeseeable and unintended, and identifying the most applicable approach to analysing large-scale biofuel production in the Western Cape, as a complex system, is crucial.
The objectives of this investigation, within the context of the Western Cape, were then to:

1. identify drivers, constraints and opportunities of commercial biofuel production;

2. investigate methods to inform strategic decisionmaking and use the most appropriate method to identify and advise on key strategic areas with the aim of strengthening the business case of biofuel production;

3. provide recommendations on the way forward for the province to form part of the mandatory blending policy; and

4. conclude on the usefulness of the technique identified to assess biofuel production as part of a green economy transition.

\section{Literature review}

A review of literature concerned with biofuels is presented in order to understand and conceptualise the factors driving and influencing biofuel production. Biofuel production is subsequently identified as a complex system, and various techniques used to aid in capturing the complex nature of systems are reviewed; and the most appropriate technique is selected to simulate and evaluate the effects of biofuel production within the province.

\subsection{Biofuels as a complex system}

The need to diversify the energy supply mix in South Africa was first established in 1998 when the white paper on energy policy of South Africa (Department of Minerals and Energy, 1998, 2007) was released and became one of the focus areas in government's vision to promote and implement renewable energy in South Africa. The large-scale utilisation of renewable energy sources could have numerous advantages, including: reduced greenhouse gas emissions, the promotion of small and micro enterprises to alleviate poverty and unemployment, and attracting private investment (both foreign and local) for the commercialisation of renewable energy production. The National Biofuel Industrial Strategy, released in 2007, mandates the blending of the national liquid fuel supply with $2 \%$ (per volume) of biofuels by October 2015. The 2\% penetration level was revised from an original $4.5 \%$ due to concerns regarding the impact on food security, and the effect on energy density of blended fuels (Department of Minerals and Energy, 2007). Although an estimated $20 \%$ of the country's fuel supply is refined in the Western Cape, the province currently has no approved large-scale commercial activities aiming to produce biofuels (DOE, 2014; South African Petroleum Industry Association, 2015). If the province were to form part of the blending mandate, it would have to start producing biofuel locally or purchase biofuel from one of the approved commercial plants elsewhere in the country. Numerous studies have completed technology 
and feedstock analyses for biofuel production in the Western Cape, where canola and triticale were identified as the most feasible feedstocks to produce biodiesel and bioethanol respectively (Nolte, 2007; Davis-Knight et al., 2008; Amigun et al., 2011).

Growth in the biofuels sector is driven primarily by support for renewable energy, due to advantages such as boosting the agricultural sector and limiting global warming. Extensive networks of policies, resources, regulations and drivers are, however, involved in the biofuels industry, and major concerns include: water limitations, food security, land value and availability, biofuel quality, crop selection, fuel levies and subsidies, and the effects of large-scale production on the agricultural sector, including employment creation. The Western Cape government's drive to transition to a green economy created a need for a holistic evaluation that considers the dynamic interaction of adverse effects of biofuel production, such as: job creation, land implications, emissions, and the bottom line costs involved to comply with the mandatory blending policy.

\subsection{Systems thinking}

Systems thinking is proposed by Loorbach (2010) as an approach to capture the complexities involved in persistent society problems, whereby possible solutions to sustainability challenges are likely to lead to further complexities. This means that systems with a high level of interconnectedness and interdependence on various levels would not be accurately approached through linear, chronological thinking. Systems thinking, or complex systems theory, can be used as a language to describe the complex interactions and patterns between system components (Loorbach, 2010). Systems thinking is, therefore, an approach that considers all of the possible influencing factors in a system and establishes their interconnectedness, mainly through modelling. Figure 1 indicates the phases of a systems thinking modelling approach, as described by Maani and Cavana (2007). Having identified biofuel production as a complex system, due to the variety of interactions on various levels, a systems approach is used in an attempt to accurately describe the various expected outcomes of biofuel production.

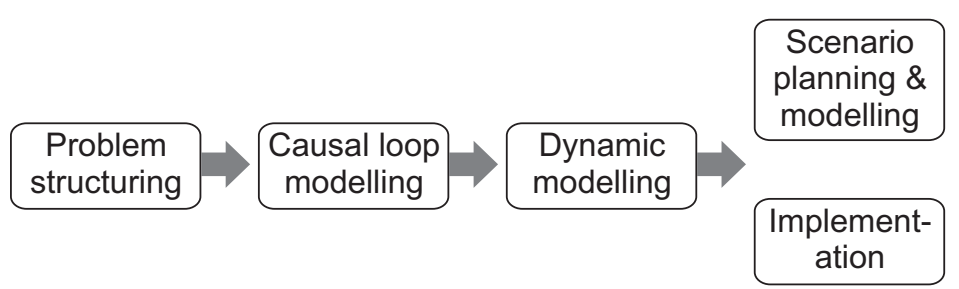

Figure 1: Phases of systems thinking (Maani and Cavana, 2007).

\subsection{Dealing with complex systems}

A variety of methods have been developed that can be used to analyse and represent complex systems. Most of these methods were developed to solve specific problems and progressively adapted to different applications. Not all methods are, therefore, equally useful under similar conditions. In order to determine the most suitable method to represent biofuel production as a system with various dynamic relations and outcomes, the pitfalls and advantages of the most relevant methodologies were investigated. Bassi (2014) highlighted that data frameworks and modelling methodologies have to be considered to generate and analyse simulations of social, economic and environmental scenarios. Some of the dynamic modelling methodologies proposed by Bassi include econometrics, optimisation, and system dynamics. Through surveying literature from various authors that applied the respective methodologies extensively, it was possible to assess each of the relevant methodologies to identify which would be best suited to simulate biofuel production as part of a green economy given the following criteria:

- Problem identification: Does the methodology assist with problem conceptualisation within the confines of the system boundary?

- Flexibility: Can the model methodology incorporate inputs from various platforms?

- Outcome accuracy: How reliable is the outcome of the simulation compared with the amount of computation time required?

- Identification of effect over time: Does the simulation deliver results as a function of time and can it model future projections?

Table 1 summarises the methodology assessment based on the work of various researchers.

System dynamics was ultimately selected as an approach to represent the complex real world problems involved in biofuel production, due to its ability to accurately represent interactions and interconnections from a variety of sectors and disciplines with relative ease. System dynamics uses a topdown approach and incorporates systems thinking to describe, model, simulate and analyse complex systems. System dynamics can adapt to parameters and inputs from various platforms and is transdisciplinary-oriented, meaning that it is suitable for research efforts conducted by investigators from different disciplines working jointly to create new conceptual, theoretical, methodological, and translational innovations that integrate and move beyond discipline-specific approaches to address a common complex problem. It is also based on principles and techniques derived from control and feedback systems, which gives it the distinct structure that directly incorporates feedback, stock and flow structures (Pruyt, 2013). 
Table 1: Modelling methodology comparison (based on Epstein, 2014; Banos et al., 2011; Bassi, 2014; Pruyt, 2013; Brailsford et al., 2014; Helbing and Balietti, 2013; Snijders et al., 2010; Le Novère, 2015).

\begin{tabular}{|c|c|c|c|c|c|c|}
\hline Methodology & Main strength & Main weakness & $\begin{array}{c}\text { Problem } \\
\text { identification }\end{array}$ & Flexibility & $\begin{array}{l}\text { Outcome } \\
\text { accuracy }\end{array}$ & $\begin{array}{l}\text { Identification } \\
\text { of effect over } \\
\text { time }\end{array}$ \\
\hline Econometrics & Based on historical trends & Absence of feedback effects & $\checkmark$ & & & $\checkmark$ \\
\hline Optimisation & $\begin{array}{c}\text { Gives an accurate estimation of } \\
\text { whether a target can be reached } \\
\text { (given set constraints) }\end{array}$ & $\begin{array}{c}\text { Does not identify the drivers } \\
\text { contributing toward reaching } \\
\text { targets }\end{array}$ & & & $\checkmark$ & \\
\hline $\begin{array}{l}\text { System } \\
\text { dynamics }\end{array}$ & $\begin{array}{l}\text { Simulation driven by root cause } \\
\text { and effect (accurately capturing } \\
\text { dynamics and feedback effects) }\end{array}$ & $\begin{array}{c}\text { Detailed input parameters, } \\
\text { or data, need to be obtained } \\
\text { across all sectors }\end{array}$ & $\checkmark$ & $\checkmark$ & $\checkmark$ & $\checkmark$ \\
\hline $\begin{array}{l}\text { Discrete } \\
\text { event } \\
\text { simulation }\end{array}$ & $\begin{array}{c}\text { Simulation (random or ordered) } \\
\text { event -driven systems, where } \\
\text { entities have to take part } \\
\text { in processes }\end{array}$ & $\begin{array}{l}\text { Rigid sequencing of events and } \\
\text { stochastic nature delivers varying } \\
\text { solutions (time-consuming to } \\
\text { run various simulations) }\end{array}$ & & & & $\checkmark$ \\
\hline $\begin{array}{l}\text { Network } \\
\text { modelling }\end{array}$ & $\begin{array}{l}\text { Identifies the most important actors } \\
\text { in a seemingly chaotic complex } \\
\text { system and shows connections } \\
\text { between entities that would } \\
\text { otherwise not easily be identified }\end{array}$ & $\begin{array}{c}\text { Limited ability to receive, } \\
\text { manipulate and produce } \\
\text { quantitative values or } \\
\text { parameters }\end{array}$ & $\checkmark$ & $\checkmark$ & & \\
\hline
\end{tabular}

\section{Methodology}

With the appropriate modelling technique identified, a model had to be developed and used to ensure that the complexity of biofuel production as a system is accurately portrayed within the model. The framework of Maani and Cavana (2007), as shown in Figure 1, was favoured for its versatile and transparent nature, which uses a systematic process that aids in facilitating model validity and ensuring repeatability.

\subsection{Problem structuring}

The main drivers and areas of concern affecting the biofuels industry were identified through surveying the latest Western Cape specific literature and consultation with industry experts (Amigun et al., 2012; Nolte, 2007; Green Cape, 2015; Fore et al., 2011). The following key aspects were consistently mentioned and directly influence the feasibility of biofuel production and the required compliance with the mandatory blending policy:

- Biofuel production plant: The type and size of plant influences building cost, resource use and production efficiency, which directly drives the capital expenditure and operational expenditure.

- Agriculture: The type of agricultural crop used has an impact on production as one has to adjudicate based on feedstock cost, availability and biofuel yield of the specific crop.

- Food security: The country's food security is dependent on the local agriculture sector, and the allocation and selection of crops to produce biofuel has to be done in a manner that will not negatively impact on food security.

- Land resources: A limited amount of land area in the Western Cape (19\% of the province's total land) is suitable for crop growth and it is important that crops grown for biofuel production do not encroach on land allocated for food crop production. The size of the plant and the type of crop used for production directly influences the land requirements.

- Water resources: Producing biofuel places additional stress on water resources through increased agricultural activities, process water, and make-up steam and cooling water.

- Energy requirements: Biofuel (especially bioethanol) production is energy-intensive and, in the midst of South Africa's energy crises, it is necessary to consider alternative energy sources and production strategies.

- By-products: Depending on the production process used, the by-product of biofuel production could strengthen the business case. Dried distillers' grains and solubles (DDGS) is a by-product of both bioethanol and biodiesel production processes and is commonly used as animal feed. Glycerine (used in the cosmetic and pharmaceutical industries) is also produced as a by-product in biodiesel production. The local market for glycerine is, however, saturated due to a large global over-supply, and glycerine then constitutes a waste management challenge.

- Biofuel sales price: The financial feasibility of biofuel production ultimately depends on in- 
Table 2: Model indicators.

\begin{tabular}{|c|c|c|}
\hline Indicator & Description & Units \\
\hline \multicolumn{3}{|c|}{ Environment } \\
\hline Emissions & Change in air emissions due to biofuel sector & $\mathrm{kg} \mathrm{CO}_{2} /$ year \\
\hline Land use & Agricultural land required for biofuel feedstock cultivation & $\mathrm{Ha}$ \\
\hline Water use & Water resources required for biofuel production & litre / year \\
\hline Electricity use & Energy used to produce biofuel & $\mathrm{kW}$ \\
\hline Biofuel by-product & Amount of DDGS produced per year & litre / year \\
\hline \multicolumn{3}{|c|}{ Social } \\
\hline Employment & Additional employment creation due to biofuel production & Person \\
\hline \multicolumn{3}{|c|}{ Economic } \\
\hline Investment into biofuel & Capital investment needed to produce biofuel & rand \\
\hline Operational cost & The running cost of a production facility to produce biofuel & rand / year \\
\hline Subsidy required & The subsidy required per litre to attain a $15 \%$ return on assets & rand / litre \\
\hline Internal rate of return & Profitability of investing into biofuel production & $\%$ \\
\hline Bottom line & $\begin{array}{l}\text { The overall bottom line cost implications of providing biofuel to the } \\
\text { Western Cape consumer through local production or inter-provincial imports }\end{array}$ & rand \\
\hline
\end{tabular}

come generated from sales. The sales price is normally defined as a percentage (based on the ratio of biofuel to fossil fuel energy density) of the basic fuel price, which is determined by the crude oil price and rand-US dollar exchange rate.

In addition to the influencing factors in the biofuel sector, indicators are used to assess the impact and feasibility of different biofuel production scenarios (Jonker, 2015). These indicators are identified and described in Table 2.
Once the drivers and indicators were identified, they could be schematically represented, in order to find the points of relation from interconnecting sectors and to serve as a visual aid and expand on possible exogenous drivers and endogenous effects.

\subsection{Causal loop modelling}

In system dynamics the visual representation of drivers and indicators is done in the form of a causal loop diagram (CLD). The CLDs consist of balancing (B) and reinforcing (R) loops, as indicated in Figure 2, where a balancing loop shows two

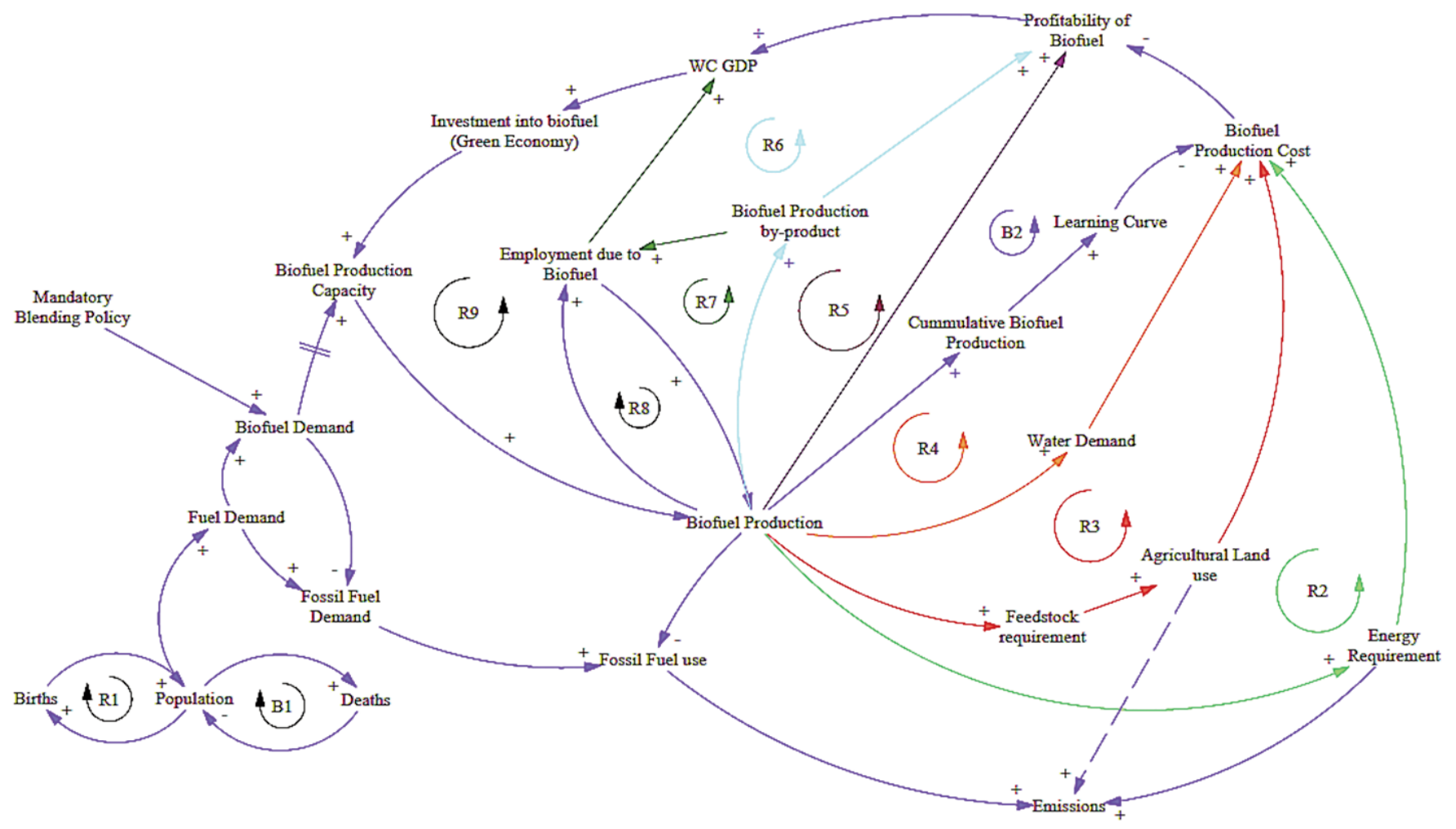

Figure 2: Biofuel sector causal loop diagram. 
entities oppositely effecting one another, while variables in a reinforcing loop influences each other to the same effect. This is best described through an example. In $\mathrm{R} 1$ an increase in population will lead to an increase in births, which again increases the population (thus reinforcing). An increase in population in B1, however, will lead to an increase in deaths, in turn decreasing the population and, consequently, balancing.

The CLD in Figure 2 shows the structure of the overall biofuel sector, by simplistically showing how fuel demand is driven by population growth. The mandatory blending policy, acting as an exogenous driver, creates a demand for biofuel, which in turn decreases fossil fuel demand and fossil fuel use. A demand for biofuel is shown to lead to biofuel production capacity, which results in biofuel production. Biofuel production is one of the main drivers and increases energy requirement, agricultural land use, water demand, by-product produced and employment, which ultimately leads back to an expansion of the biofuel production capacity (if biofuel production is financially lucrative). The CLD also indicates expected emissions being influenced by changes in fossil fuel use and the production of biofuel (through energy requirements and increased agricultural activities).

\subsection{Dynamic modelling}

The model-building phase resulted in the construction of eight core sub-models. These models are described in detail by Jonker (2015), and include: biofuel production, agricultural yield, biofuel expenditure, operational finances, profitability, alternatives to local production, employment, and emissions. Figure 3 shows an extract from the operational finances sub-model, and is shown here to illustrate the key concept and working of system dynamics. From Figure 3 it can be seen how biofuel feedstock crop cost will increase annually with the biofuel feedstock cost increase, which is driven by a percentage increase (feedstock increase rate) as well as the effects of demand and supply on market prices. The time horizon of the simulation is 2001 to 2040, where the 2001 census data provided accurate initial values for the model. This simulation time also provides sufficient historic simulation results in order to validate the model behaviour and outputs.

The biofuel model consists of eight sub-models, which are interconnected and represents the dynamics involved in biofuel production. The biofuel model further received input and information regarding agricultural activities, from a larger model (WeCaGEM), which describes the Western Cape's transition to a green economy (Musango et al., 2015).

\subsection{Scenario planning}

In order for a model to be usefull and acurate, Senge (1980) mentioned that confidence in the model output has to be established. Numerous validation techniques are available to ensure that model structure and outputs are acurate, and the validation techniques as set out by Senge (1980) and Maani and Cavana (2007) were followed in this study. This included validating the model structure with independent industry specialists, cross-referencing model parameters with real-life expected values, and completing an extreme conditions and boundary adequacy test to ensure that the model responds logically. To further validate the model, dimensional consistency was checked and model behaviour was analysed against expected behavior and trends (Jonker, 2015).

Once the model was validated, a sensitivity analysis was done on variables that can be changed or determined endogenously. Electricty price was found to be one of the key endogenous variables influencing the success of local production (LP) scenarios. Different project scenarios were thus generated to look at the feasibility of generating electricity

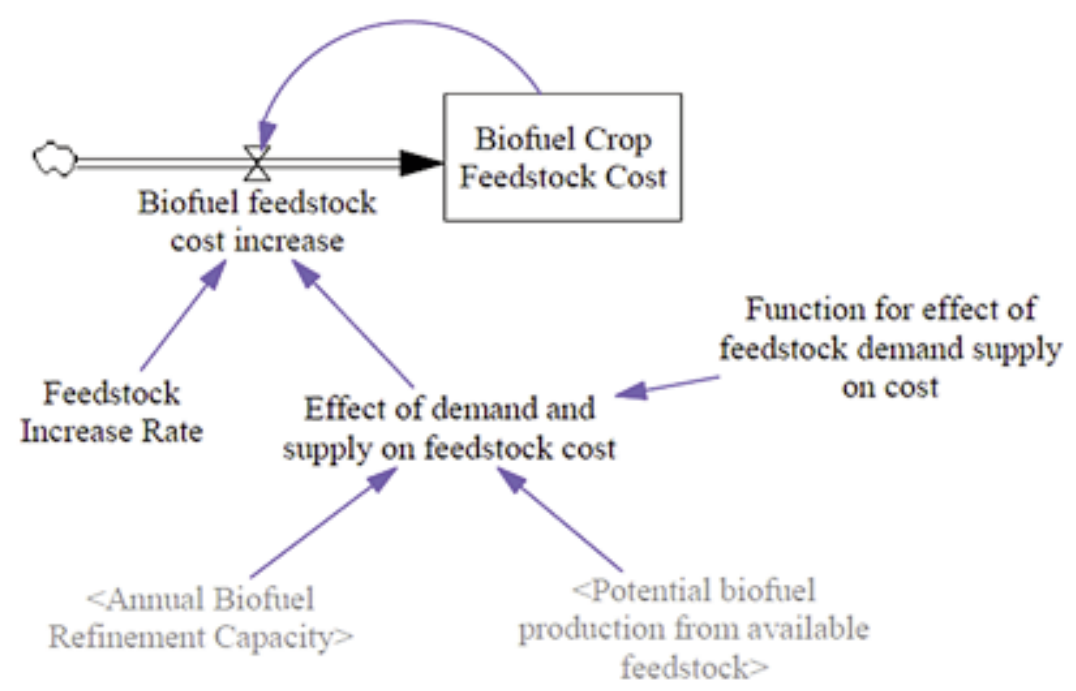

Figure 3: Biofuel feedstock cost. 
on-site and incorporating electricity sales as part of the business case. As mentioned earlier, it was also necessary to look at the alternative solution for the Western Cape to form part of the mandatory blending requirement, which will see the province purchasing biofuel from existing plants elsewhere in the country; in other words non-local production (NLP). The following six scenarios were identified and used as comparison to assesss the impacts and effects of complying with the mandatory blending requirement on a provincial level:

1. LP (boiler-coal): A local production scenario using a conventional coal-fired boiler to provide process heat.

2. LP (boiler-biomass): A local production scenario using a biomass-fired boiler for process heat.

3. LP (CHP-coal): A local production scenario where a combined heat and power (CHP) unit using coal is installed to provide the production facility with process heat and electricty (where surplus electricty can be sold to the national grid).

4. LP (CHP-biomass): Biomass is used instead of coal to fuel the CHP mentioned in sceanrio 3.

5. NLP (coal): A non-local production sceanrio, which evaluates the effects of buying biofuel in from a different province. To provide objective comparison of the emissions produced it is assumed that the said plant uses a coal fired boiler.

6. NLP (biomass): A non-local production scenario identical to scenario 5 , but assuming the boiler is fuelled through the use of biomass.

\section{Modelling outcomes}

\subsection{Biofuel production}

The biofuel production sub-model simulated bioethanol and biodiesel production capacity and actual production volumes. The biofuel capacity model assumed that two facilities producing 160

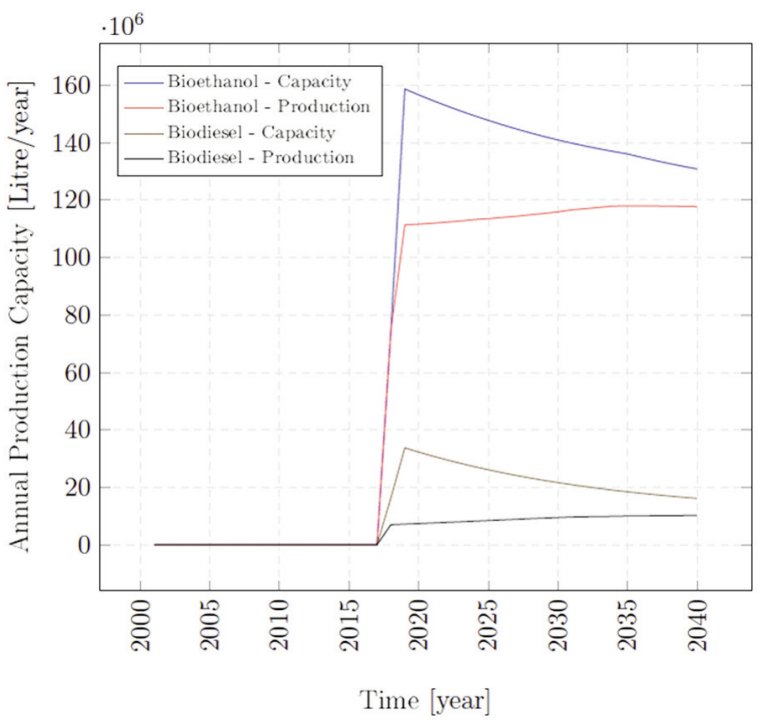

Figure 4: Biofuel capacity and production. million litres/annum of bioethanol and 35 million litres/annum of biodiesel will be completed by 2018 (GreenCape, 2015). Figure 4 shows biofuel production capacity and the actual biofuel production. The graph shows how actual production is less than production capacity and how, subsequently, production capacity decreases based on the reduction in required production capacity due to biofuel feedstock limiting the amount that can be produced.

Figure 5 shows the amount of cropland available for biofuel crop production, based on the inputs received from the agricultural sub-model in WeCaGEM. The biofuel production model asssumed $25 \%$ of the current canola land to be allocated to biodiesel production and a four-year crop rotation cycle for triticale cultivation to produce bioethanol. The effects of farmer uptake of triticale cultivation were incorporated and based on the sales price of triticale compared with B3-grade, or utility-grade, wheat, which is the lowest quality wheat grading, resulting in a substantially lower selling price when compared with $\mathrm{B} 1$ grade. The farmer uptake is a function of the expected sales price of utility-grade wheat compared with the expected sales price of triticale, and it is assumed that, if the sales price of triticale were higher than than of utility grade wheat, the farmer would allocate (over time) the portion of land (based on historical fractions) yielding utility grade wheat to the cultivation of triticale. The model assumes that the sales price of triticale will initially be equal to that of utility grade wheat and therafter dynamically adjust based on supply and demand as illustrated by Figure 3. Due to triticale's notable ability to grow in marginal soil, experts suggest that, in addition to crop rotation land available an additional 70000 ha of uncultivated land is available for triticale cultivation in the Western Cape, which contributed to the production capacity (Amigun et al., 2011).

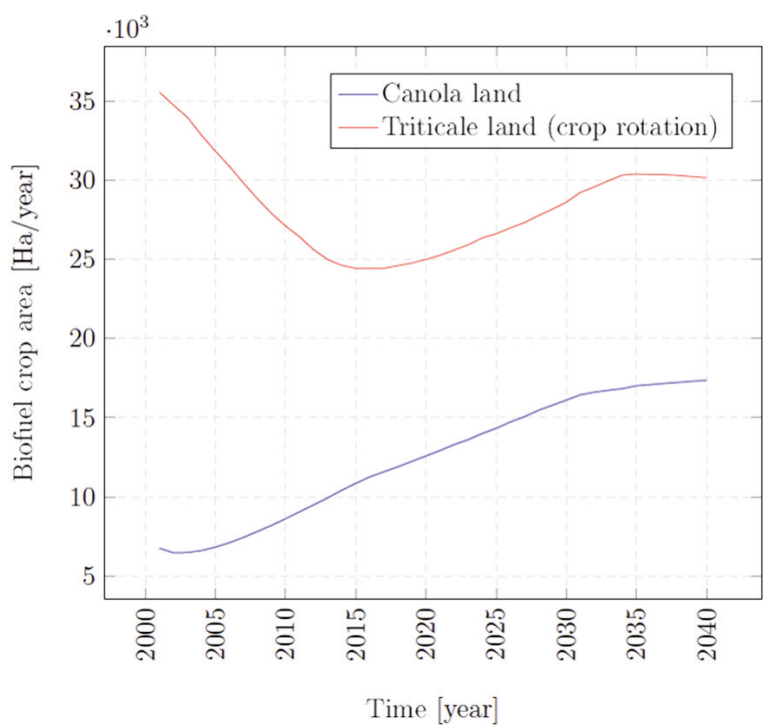

Figure 5: Crop production area in the Western Cape. 
Figure 6 shows how the biofuel production under the current feedstock assumptions are not sufficient to meet the biodiesel demand of the province, based on fuel demand and mandatory blending requirements.

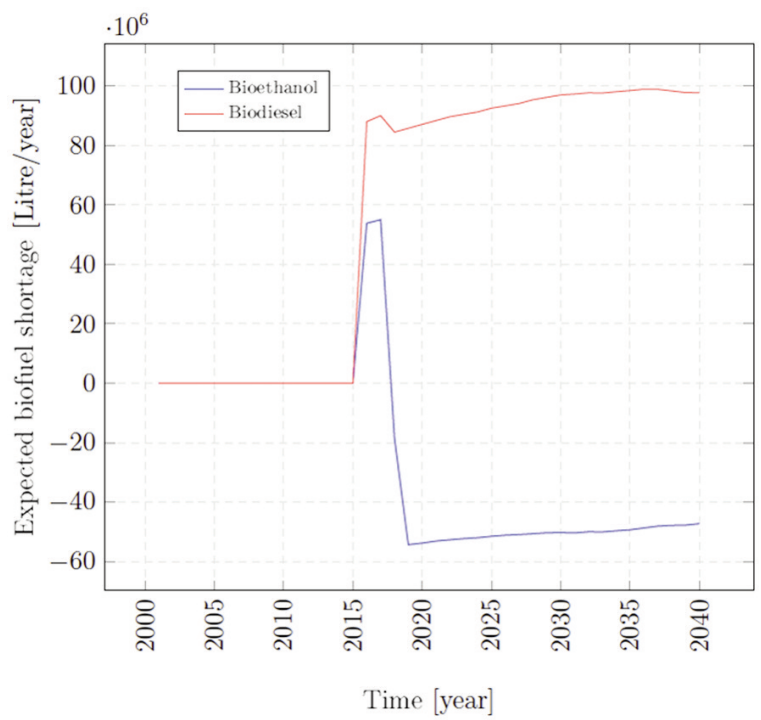

Figure 6: Expected biofuel shortage in the Western Cape.

\subsection{Biofuel expenditure}

Table 3 shows the expected annual operational expenditure, and it is evident that costs are expected to increase drastically for both bioethanol and biodiesel production. It should be noted that the CHP scenarios (3 and 4) only have marginally higher operating costs than the boiler scenarios (1 and 2 ) by the year 2038, due to the dependence of operational cost on rising electricity costs.

The increase in operational expenditure is driv- en by the increase in operational or input costs. Table 4 shows the various input costs where the low estimated cost of triticale and the high value of DDGS are some of the key factors driving the successful business case of bioethanol production. The simulation also highlights factors impeding the establishment of a biodiesel sector; these include the high cost of canola and the comparatively weak market value of biodiesel by-product. In addition, water, energy, labour and chemical costs are expected to increase by $5-8 \%$ per annum, based on historical trends.

\subsection{Profitability}

Although it is commonly acknowledged that the biofuel industry brings advantages like a reduction in greenhouse gas emissions and employment creation, attracting investment ultimately depends on the profitability of the industry. In order to attract investors, the national biofuel industrial strategy proposed a subsidy to be paid to producers to ensure a $15 \%$ return on assets (ROA) as defined by Equation 1 (DOE, 2014):

$\mathrm{ROA}=\frac{\text { Earning before interest and taxes }}{\text { Total assets }}$

The value of assets is initially estimated to be R900 million and R200 million for the respective bioethanol and biodiesel facilities, making use of grid-provided energy and a boiler for process heat (scenarios 1 and 2). Scenarios 3 and 4, including the $\mathrm{CHP}$ unit, are considerably more expensive because of the estimated installed capacity cost of ZAR 51000 to ZAR58 000 per kW. This requires an investment of respectively R2 810 million and R2 120 million for bioethanol and biodiesel production facilities, including a $33 \mathrm{MW} \mathrm{CHP}$. The value of

Table 3: Operational expenditure (R million).

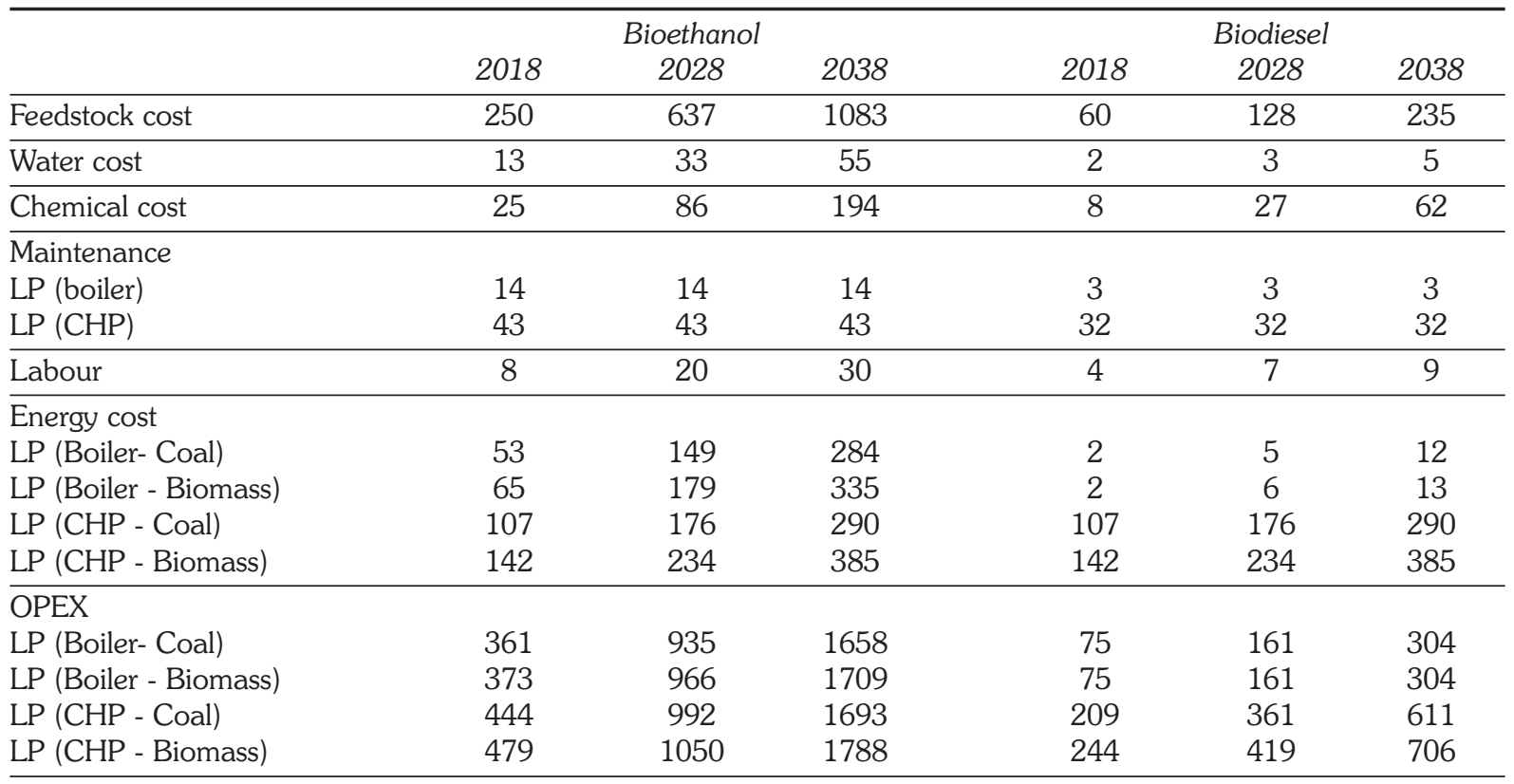


Table 4: Operating costs.

\begin{tabular}{lcccc}
\hline & Units & 2018 & 2028 & 2038 \\
\hline $\begin{array}{l}\text { Biofuel crop feedstock cost } \\
\text { Bioethanol - triticale }\end{array}$ & Rand/ton & 1571 & 2604 & 4319 \\
Biodiesel - canola & Rand/ton & 3841 & 6343 & 10491 \\
\hline Technical and administrative wages & Rand/person/hour & 24 & 38 & 60 \\
\hline Management salary & Rand/person/year & 545847 & 864092 & 1368000 \\
\hline Water unit cost & Rand/kilolitre & 6.54 & 10.78 & 17.76 \\
\hline Combustible cost & & & & 1046 \\
Biomass & Rand/ton & 385 & 635 & 1763 \\
Coal & Rand/ton & 650 & 1018 & 2.21 \\
\hline Electricity cost & Rand/kWh & 0.45 & 1 & 863.94 \\
\hline Chemical & & & & 58.53 \\
Bioethanol - yeast & Rand/kg & 175.12 & 388.97 & 22.99 \\
Bioethanol - enzyme & Rand/kg & 112.61 & 250.11 & 10.35 \\
Biodiesel - methanol & Rand/kg & 4.66 & 18.97 & 43.14 \\
Biodiesel - catalyst & Rand/kg & 8.54 & & 9578 \\
\hline By-product selling price & Rand/ton & 1942 & 4312 & 13026 \\
Bioethanol - DDGS & Rand/ton & 2640 & 5865 & \\
Biodiesel - canola oilcake & & & & \\
\hline
\end{tabular}

assets is expected to decrease over the expected lifetime (20 years) of the facility. In addition to the subsidy required to achieve the guaranteed ROA, the model simulates the internal rate of return (IRR) for the various local production scenarios to assess the financial feasibility of biofuel production. Bioethanol shows a strong business case, requiring no subsidy to achieve the $15 \%$ ROA. Scenario 1 and 2 produced higher ROA values than scenario 3 and 4 due to the high capital cost of incorporating a CHP unit. The IRR values also indicated scenarios 1 and 2 to be the most lucrative, with IRR values of $25 \%$ and $23 \%$ respectively. For biodiesel production, none of the local production scenarios proved to be a feasible business case. Scenarios 1 and 2 required subsidies of between ZAR 4.30 and ZAR
1.70 per litre of biodiesel, while scenarios 3 and 4 require unrealistically high subsidies to reach the $15 \%$ ROA. The CHP scenarios again compared poorly with each other in the financial analysis, due to the substantial capital requirements. The IRR values for all of the biodiesel scenarios were large negative values over most of the project lifespan.

\subsection{Bottom line cost}

The bottom line cost refers to the overall cost of complying with the blending mandate and incorporates scenarios 5 and 6 (non-local production), which will see the Western Cape buying biofuel from existing biofuel producers. The local and nonlocal production scenarios for bioethanol and biodiesel are shown in Figures 7 and 8. For bio-

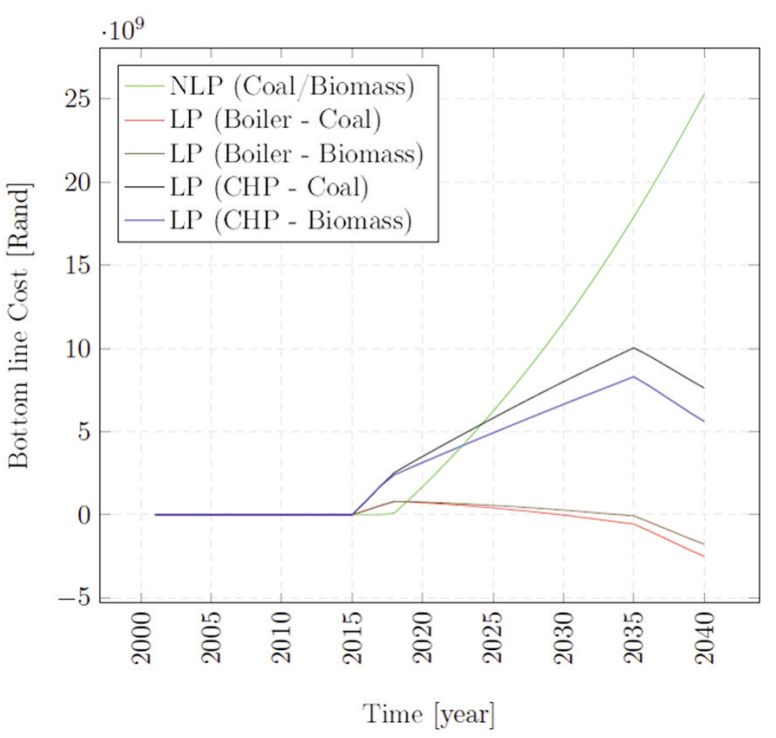

Figure 7: Bottom-line cost (bioethanol).

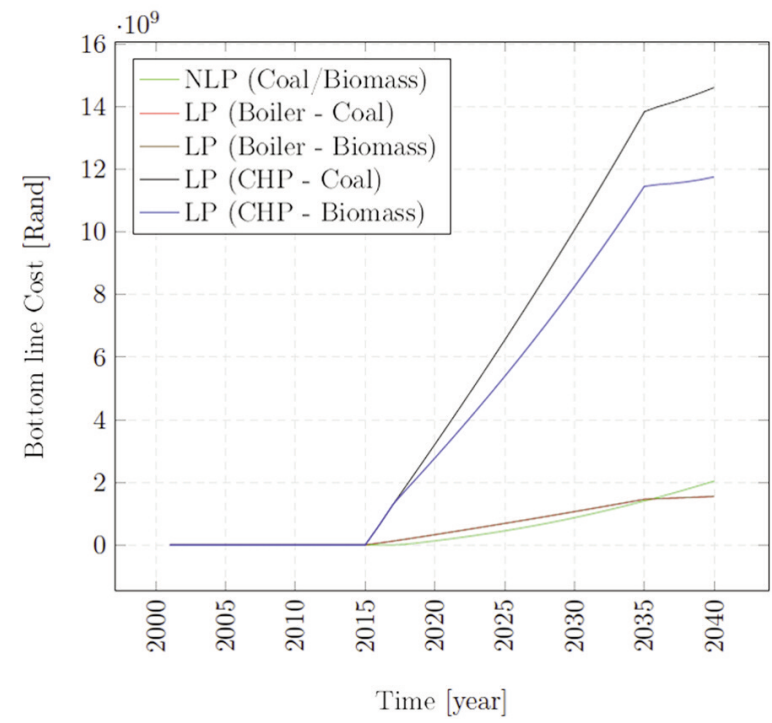

Figure 8: Bottom-line cost (biodiesel). 
ethanol, the non-local production scenarios initially have lower associated costs, but will exceed the costs of all of the local production scenarios by 2025 because of the continued expenditure on purchasing and transporting bioethanol with very little income being generated by the non-local production scenarios. Figure 8 shows the bottom-line cost for biodiesel, where the cost of the local production scenarios making use of the CHP unit far exceeds the local production scenarios 1 and 2 , as well as the non-local production scenarios. The non-local production bottom-line costs only marginally exceed scenarios 1 and 2 in 2036, meaning that for the majority of the estimated project lifespan it is expected to be cheaper to purchase biodiesel from existing production facilities, rather than producing biodiesel locally.

\subsection{Employment}

In evaluating employment created through a biofuel sector, only direct additional job creation was considered. Employment in the biofuel production sector can vary greatly, based on production method, scale and level of automation used. To simulate employment creation, historical data of employees required per area of cropland (33.64 employees/ hectare) farmed, and an employment ratio per litre of biofuel produced was incorporated into the model (Karaan, 2010; National biofuels study, 2006). It is estimated that the bioethanol plant will create roughly 2080 jobs through expansion of the agricultural sector and an average of 55 additional jobs involved in operational duties. Biodiesel production creates relatively few jobs, with between 10 and 15 additional jobs expected, due to the scale of the operation and the use of existing canola crops (thus not increasing agricultural activity).

\subsection{Emissions}

The emissions produced by the various scenarios depend mainly on the process used and, as expected, the scenarios making use of energy from coal showed substantially higher emissions. The bioethanol production facility utilising biomass for energy showed $63 \%$ less emissions than the coalfired counterpart. Biodiesel production using biomass showed a $5 \%$ reduction in emissions when compared with a coal-fired facility due to the scale of the operation.

For bioethanol and biodiesel the non-local production scenarios showed higher emissions than local production, due to the additional emissions caused by transporting the biofuel from established facilities by road. Emissions were evaluated on the amount of carbon dioxide produced per litre of fuel burned; refer to Jonker (2015) for the detailed factors and boundaries used to calculate the respective carbon footprints.

\subsection{Scenarios summary and recommendations}

All of the scenarios were evaluated according to the indicators identified (see Table 2). Recommendations to facilitate complying with the mandatory blending policy in the Western Cape are summarised below, and is discussed in detail in the work of Jonker (2015).

\subsubsection{Bioethanol}

The Local production scenario 2 (boiler-biomass) is recommended, as an IRR of $23 \%$ is achieved, while emissions are $63 \%$ lower than for the coal-fired option. To strengthen the business case of bioethanol production, the following factors should be addressed:

1. Improve feedstock availability through utilising uncultivated marginal land.

2. Reduce capital costs through alternative financing options.

3. Incorporate bioethanol production as part of an invasive alien land-clearing scheme.

\subsubsection{Biodiesel}

It is recommended that biodiesel is not locally produced (scenarios 5 and 6). The current operation scale and feedstock assumptions do not provide a compelling business case for local biodiesel production. Furthermore, the social and environmental advantages from biodiesel production does not provide sufficient incentive to justify the financial and infrastructure burdens associated with a project of this scale and nature. Further work is recommended in the following areas to establish more feasible biodiesel production options:

1. Investigate different and combined feedstock options.

2. Consider systems and policies to encourage small-scale biodiesel production.

3. Re-evaluate the value stream of biodiesel.

\subsection{Approach evaluation}

System dynamics is a powerful modelling technique to holistically describe complex systems and is favoured for its versatile and robust nature. One of the disadvantages is, however, the extensive knowledge and data required on every part of the system in order to accurately isolate the root causes and drivers of the system. Some elements may be overlooked or simplified based on the dispositions of the stakeholders, although various stakeholders and experts were engaged to determine the system structure (see Jonker, 2015). An iterative and interactive process is thus required to build a model that comprehensively captures the true nature of a complex system. Lack of available data and an established biofuel sector in South Africa (and particularly the Western Cape) necessitated a biofuel project evaluation model to be built. Such models generally 
require the use of switches that inhibits the dynamic and feedback effects within the system. The largest drawback of the model is thus that it did not effectively incorporate feedback and dynamic linkages from the green economy model (WeCaGEM). Although it received inputs from WeCaGEM, the model did not indicate any emergent system behaviour. System dynamics was successfully used for the project evaluation of establishing a biofuel sector, but future work is recommended to incorporate the biofuel model into a larger model in order to gain an in-depth understanding of the adverse effects of biofuel production as part of a green economy transition.

\section{Conclusions}

This study investigated the literature available on policies in the biofuel sector in South Africa and evaluated different techniques suitable for the evaluation of biofuel production as part of a larger complex system. A system dynamics model was developed to describe and evaluate the various effects of complying with the mandatory biofuel blending requirement under different scenarios. After evaluation of the different scenarios, it was recommended that bioethanol is produced locally using biomass for process heat and biodiesel to be bought in from existing production plants if necessary. The usefulness and applicability of system dynamics as a modelling technique for biofuel production as part of the green economy was investigated and it was concluded that it is extremely well suited for the representation of interrelated complex systems. System dynamics is not necessarily the best approach if one is purely interested in doing a project evaluation, but nonetheless provides valuable insight into the key drivers and intervention points for the evaluation of a system.

\section{References}

Amigun, B., Petrie, D. and Görgens, J. 2011. Economic risk assessment of advanced process technologies for bioethanol production in South Africa: Monte Carlo analysis. Renewable Energy 36(11): 3178-3186.

Amigun, B., Petrie, D. and Görgens, J. 2012. Feedstock and technology options for bioethanol production in South Africa: techno economic prefeasibility study. Energy \&Fuels 26(9): 5887-5896.

Banos, R., Manzano-Agugliaro, F., Montoya, F., Gil, C., Alcayde, A. and Gomez, J. 2011. Optimization methods applied to renewable and sustainable energy: A review. Renewable and Sustainable Energy Reviews 15(4): 1753 - 1766.

Bassi, A.M. 2014. Review of business and economics studies. Quarterly 2 (1): 88-97.

Brailsford, S., Churilov, L. and Dangerfield, B. 2014. Discrete-event simulation and system dynamics for management decision making. John Wiley and Sons.
Davis-Knight, H.R. and Weightman, R.M. 2008. The potential of triticale as a low input cereal for bioethanol production. Home-Grown Cereals Authority. Available online at: http://cereals.ahdb. org.uk/media/408618/pr434-final-project-report.pdf (accessed 14 January 2016.

Department of Energy (DOE) 2012. Government Gazette r. 671. Available online at: http://www.energy.gov.za/files/policies/Mandatory\%20Blending\%20R egulations\%2024\%20August\%202012.pdf (accessed 14 January 2016).

Department of Energy (DOE) 2014. Draft position paper on the South African biofuel regulatory framework. Government Gazette no. 37232. Available online at: http://www.gov.za/sites/www.gov.za/ files/37232gen24.pdf (accessed 14 January 2016).

Department of Minerals and Energy 1998. White paper on the energy policy of theRepublic of South Africa. Available online at: http://www.energy.gov.za/files/ esources/petroleum/wp_energy_policy_1998.pdf (accessed 14 January 2016).

Department of Minerals and Energy 2007. Biofuels industrial strategy of the Republic of South Africa. Available online at: http://www.energy.gov.za/files/ esources/renewables/biofuels_indus_strat.pdf(2).pdf (accessed 14 January 2016).

Epstein, R.J. 2014. A history of econometrics. Elsevier, North Holland.

Fore, S.R., Porter, P. and Lazarus, W. 2011. Net energy balance of small-scale on-farm biodiesel production from canola and soybean. Biomass and Bioenergy 35(5): 2234-2244.

GreenCape 2015. Biofuels: from viability to pilot project (re-assessment of the Western Capes biofuel production potential via a multi-criteria analysis). Cape Town. Available online at: http://greencape.co.za/ what-we-do/projects/biofuels/ (accessed 14 January 2016).

Helbing, D. and Balietti, S. 2013. How to do agentbased simulations in the future: From modelling social mechanisms to emergent phenomena and interactive systems design. In: Helbing D (ed). Social self-organization: Agent-based simulations and experiments to study emergent social behavior. Springer, Berlin: 25-70.

Jonker, W.D. 2015. Biofuel implications of a green economy transition in the Western Cape province of South Africa: A system dynamics modelling approach to biofuel. Masters thesis, Stellenbosch University. Available online at: http://hdl.handle.net/ 10019.1/97865 (accessed 14 January 2016).

Karaan, M. 2010. Can agriculture create a million jobs? Paper presented at AgriSA Conference 2010, Muldersdrift, Gauteng, 8 October 2010.

Le Novère, N. 2015. Quantitative and logic modelling of molecular and gene networks. Nature Reviews Genetics 16(3): 146-58.

Loorbach, D. 2010. Transition management for sustainable development: A prescriptive, complexity-based governance framework. Governance, 23(1): 161183.

Maani, K. and Cavana, R.Y. 2007. Systems thinking, system dynamics: Managing change and complexity. Prentice Hall. 
Musango, J.K., Brent, A.C., van Niekerk, J.B.S., Jonker, W.D., Pienaar, A.P., York, T.A., Oosthuizen, J., Duminy, L. and de Kock, I.H. 2015. A system dynamics approach to understand the implications of a green economy transition in the Western Cape Province of South Africa. paper presented at the $33^{\text {rd }}$ International Conference of the System Dynamics Society, Boston, USA.

National Planning Commission 2012. National development plan 2030. Our future: Make it work. Pretoria. Available online at: http://www.gov.za/documents/ national-development-plan-2030-our-future-make-itwork (accessed 14 January 2016).

National Biofuels Study 2006. An investigation into the feasibility of establishing a biofuels industry in the Republic of South Africa. Available online at: http://www.mabelefuels.com/wp-content/uploads/ 2011/12/National-Biofuels-Study.pdf (accessed 7 December 2016).

Nolte, M. 2007. Commercial biodiesel production in South Africa: A preliminary economic feasibility study. Masters thesis, Stellenbosch University. Available online at: http://hdl.handle.net/10019.1/ 1797 (accessed 14 January 2016).

Pruyt, E. 2013. Small system dynamics models for big issues: Triple jump towards real-world complexity. Delft University of Technology. Available online at: http://simulation.tbm.tudelft.nl/smallSDmodels/Intro.h tml (accessed 14 January 2016).

Senge, P.M. 1980. Tests for building confidence in system dynamics models. System dynamics TIMS Studies in Management Sciences 14: 209-228.

South African Petroleum Industry Association (2015 June). Industry overview - South African fuel industry. Available online at: http://www.sapia.co.za/industry-overview/fuel-industry.html (accessed 18 January 2017).

Snijders, T.A., van de Bunt, G.G. and Steglich, C.E. 2010. Introduction to stochastic actor-based models for network dynamics. Social Networks 32(1): 44 60.

United Nations Environment Programme (UNEP). 2010. Driving a green economy through public finance and fiscal policy reform. Paris. Available online at: http://www.unep.org/greeneconomy/Portals/88/documents/ger/GER_Working_Paper_Public_Finance.pdf (accessed 14 January 2016).

Western Cape Government (2013). Green is smart. Cape Town. Available online at: https:/www.westerncape.gov.za/110green/tags/green-smart (accessed 14 January 2016). 